\title{
Experimental model to induce obesity in rats ${ }^{1}$
}

\author{
Modelo experimental para induzir obesidade em ratos
}

\author{
Vinicius Von Diemen², Eduardo Neubarth Trindade ${ }^{3}$, Manoel Roberto Maciel Trindade $^{4}$ \\ 1. Research performed at Department of Surgery, Post-Graduate Program in Surgery, Medical School, Federal University of Rio Grande do \\ Sul (UFRGS). Brazil. \\ 2. Fellow Master degree, Post-Graduate Program in Surgery, UFRGS. Brazil. \\ 3. Graduate student, UFRGS. Brazil. \\ 4. PhD, Associate Professor, Department of Surgery, Post-Graduate Program in Surgery, UFRGS. Brazil.
}

\begin{abstract}
The etiology of obesity is multifactorial and is becoming a problem of public health, due to its increased prevalence and the consequent repercussion of its comorbidities on the health of the population. The great similarity and homology between the genomes of rodents and humans make these animal models a major tool to study conditions affecting humans, which can be simulated in rats. Obesity can be induced in animals by neuroendocrine, dietary or genetic changes. The most widely used models to induce obesity in rats are a lesion of the ventromedial hypothalamic nucleus (VMH) by administering monosodium glutamate or a direct electrical lesion, ovariectomy, feeding on hypercaloric diets and genetic manipulation for obesity.
\end{abstract}

Key words: Obesity. Models, Animal. Metabolism. Rats.

\section{RESUMO}

A obesidade tem etiologia multifatorial e está se tornando um problema de saúde pública devido ao aumento da sua prevalência e a conseqüente repercusão das suas comorbidades na saúde da população. A grande similaridade e homologia entre os genomas dos roedores e dos humanos tornam esses modelos animais uma importante ferramenta para o estudo de condições que afetam os humanos e que podem ser simuladas em ratos. A obesidade pode ser induzida em animais com alterações neuroendócrinas, dietéticas ou genéticas. Os modelos mais utilizados para indução de obesidade em ratos são lesão do núcleo hipotalâmico venteromedial (VMH) através da administração de glutamato monossódico ou lesão elétrica direta, ooforectomia, alimentação com dietas hipercalóricas e manipulação genética para obesidade.

Descritores: Obesidade. Modelos Animais. Metabolismo. Ratos.

\section{Introduction}

The etiology of obesity is multifactorial, and it is reaching epidemic proportions. Even at low levels it has evil effects on health and is associated with a shorter life expectancy ${ }^{1}$. The adverse clinical consequences of obesity are so harmful that a $20 \%$ increase above the ideal weight is associated with a $20 \%$ increase in the mortality rate ${ }^{2}$.

Obesity may be defined as excess weight with a body mass index (BMI) greater than $30 \mathrm{~kg} / \mathrm{m}^{2}$. Morbid obesity is a more serious condition, which is correlated with a weight $170 \%$ greater than the ideal weight, or overweight greater than $45.360 \mathrm{Kg}$ (100 pounds), or, else, a BMI greater than 40 $\mathrm{kg} / \mathrm{m}^{2}{ }^{1}$ The induction of obesity may be performed in animals by neuroendocrine, dietary or genetic changes. The study of these models has shown that it is the central nervous system that regulates energy expenditure and food intake, and it has also identified interrelationships among adrenal glucocorticoids, the autonomic nervous system and dietary behavior in the development of obesity ${ }^{3,4}$. The great similarity and homology between the genomes of rodents and humans make these animal models a major tool to study obesity. The animals enable us to obtain answers in a short time, since 10 days in the life of a rat are approximately 1 year in humans when comparing changes in body weight. Some obesity-induction models in rats are found in the literature and among them all, the main ones are a lesion of the ventromedial hypothalamic nucleus (VMH) which can be achieved mainly in two ways (administration of monosodium glutamate or direct electrical lesion) ${ }^{5,6}$, ovariectomy $^{7}$, feeding on hypercaloric diets ${ }^{8,9}$ and genetic manipulation for obesity.

\section{Models}

1. Ventromedial hypothalamic nucleus (VMH) lesion

\subsection{Monosodium Glutamate (MSG)}

The administration of monosodium glutamate to newborn rats causes the destruction of the ventromedial hypothalamic and arcuate nuclei, leading the rats to develop obesity due to the lack of control between absorption and energy expenditure. The real mechanism by which this 
hypothalamic injury leads to obesity is not known, but what is known is that it is not because of increased food intake. In a single dose during the neonatal period, although it did not develop obesity, MSG caused a drop in the hypothalamic dopamine ${ }^{10}$. The involvement of enzyme activity of the small bowel in the induction of obesity after the use of MSG and the influence of the adrenal gland have been researched ${ }^{11-}$ ${ }^{13}$. MSG has shown a number of changes related to the lack of control of the hypothalamo-pituitary axis with a dosedependent curve including hypophagia, obesity, hypoactivity, reduction of ovarian weight, late puberty and high serum levels of corticosteroids ${ }^{14,15}$. There is evidence that chronic exposure of the adrenal gland to high serum levels of leptin, which occurs in rats treated with MSG, is involved in the loss of the inhibitory regulatory effect that leptin exerts on the adrenal gland. Therefore, it is responsible, at least in part, for the increase of glucocorticoids found in these adult rats ${ }^{16,17}$. MSG can be administered subcutaneously or intraperitoneally ${ }^{18,19}$ at doses that vary by $2-4 \mathrm{mg} / \mathrm{g}$ of body weight of the rat during the neonatal period and for periods ranging by 4-10 doses causing obesity ${ }^{20-24}$. Since MSG is a substance found in several foods consumed daily, it has been targeted by studies on its effects when taken orally. Diniz et al, in a recent publication, compared 4 groups of rats, one fed standard chow, another standard chow added to $100 \mathrm{~g}$ of MSG/kg of weight, a fiber-rich diet and another with a fiber rich diet added to $100 \mathrm{~g}$ of MSG/kg of weight. In this study, MSG increased food intake, induced metabolic disorders associated with oxidative stress (prevented in the group with a fiber-rich diet), even in the absence of obesity, and also presented a rise in the glucose, trialglycerol, insulin (with increased peripheral resistance) ${ }^{25}$ and leptin ${ }^{26}$ levels.

\subsection{Electrical VMH Lesion}

The VMH lesion was described by Saito et al (1985) and now, with a few changes, it can be used to induce obesity. A $1.2 \mathrm{~mA}$ current lasting 4 seconds, repeated 3 times at 30-second intervals after positioning the electrodes, can cause bilateral destruction of the hypothalamic nuclei, leading to obesity. The tip of the guinea pig's nose is positioned $5 \mathrm{~mm}$ above the interaural line in a stereotactic instrument, and the electrode tip is placed $0.6 \mathrm{~mm}$ lateral to the bregma and $9 \mathrm{~mm}$ below the cranium ${ }^{6}$. As described by Dube et al the injury can also be caused with a single electrical current of $2.5 \mathrm{~mA}$ for 15 seconds using stereotactic instruments placing the tip of the rat nose $3.3 \mathrm{~mm}$ below the interaural line and positioning the tip of a stainless steel electrode $2.6 \mathrm{~mm}$ behind the bregma, 0.5-0.6 mm lateral to the midline and below the base of the brain and raised 0.5 $\mathrm{mm}{ }^{27}$. Paradoxically, concerning what was found in the hypothalamic lesiong by MSG, this electrical ablation causes obesity by hyperphagia. The real mechanism involved in this process is not known. Initially the irritative theory was believed, in which the deposition of iron ions caused by the introduction of electrodes in the hypothalamus would destroy the hypothalamic nuclei over the long term.. Other authors suggested that the injury was caused only by the electric current, the ablative theory. Studies were performed comparing electric injury with radiofrequency (without ion deposition) using the conventional technique and the results obtained were a lower index of obesity using radiofrequency. Therefore, the most widely accepted theory is ablative/ irritative, i.e. both mechanisms are involved in the development of obesity ${ }^{28-31}$. More recent studies have shown involvement of the participation of leptin, insulin and neuropeptide $\mathrm{Y}$, and their interrelations in the hypothalamus, causing weight gain after this type of lesion 32,33 . It is known that the electric lesion of the hypothalamus causes an increased level of leptin, reduction of the total neuropeptide Y, maintaining the fluctuations of the circadian rhythm and there appears to be a loss of the feedback mechanism between insulin and leptin ${ }^{34}$.

\section{Oophorectomy}

The obesity induction model in rats through oophorectomy, on the contrary of the previous ones, results from the observation of women who, after menopause, present a number of metabolic changes, including weight gain. This model is used in order to achieve a better understanding of these modifications in women after the end of their fertile age and also to study interventions that could alter the impact of hormone reduction in a woman. The removal of gonads from female rats causes a drop in the initial leptin levels, which is correlated with a period of hyperphagia and marked weight gain. Seven weeks after ovariectomy, the leptin levels rose again reaching much higher levels that the preoperative ones. It is not known whether this increase is due to resistance to leptin, and could involve hypothalamic receptors, o to the increased production due to weight gain itself, since the studies are conflicting $^{35-40}$. More recent studies have tried to find changes in the expression of genes related to energy expenditure in ovariectomized rats to account for weight gain $^{41}$. It appears that leptin and estradiol do not regulate themselves directly, because both administering the former and the latter in intact female rats did not show that it altered either of them, and the reciprocal is true ${ }^{42,43}$. Therefore it is believed that there is a factor responsible for alerting the hypothalamus to the fact that estrogen production has ceased. A few studies speculate on the participation of neuropeptide Y. It appears to serve as a signal to the hypothalamus that the estrogen levels have dropped, since it would be raised after ovariectomy and would remain at the same levels if hormone replacement occurred in the female rats ${ }^{44-46}$.

\section{Hypercaloric diets}

This is the simplest obesity-induction model, and possibly the one that most closely resembles the reality of obesity in humans. There are several types of diets to induce obesity that have proved effective. A few diets attain hypercaloric values by adding carbohydrates and others by fats, and most of them vary between $3.7 \mathrm{Kcal} / \mathrm{g}$ and 5.4 $\mathrm{Kcal} / \mathrm{g}$. All of them are highly palatable and induce obesity. In order to provide an idea of these diets, two models will be mentioned next, based on carbohydrate addition, and two others with fat addition. Naderali et al, in an experimental study with male Wistar rats, used a diet containing 33\% 
standard chow, 33\% Nestlé ${ }^{\circledR}$, condensed milk, 7\% saccharine and $27 \%$ water for 15 weeks, reaching a mean weight of 680.2 grams with a standard deviation of 8.7 grams. During this same period, rats fed pure chow weighed an average of 570.2 grams $^{47}$. Another author, studying gastric "bypass" models in Sprague-Dawley rats, induced obesity with food consisting of $48 \%$ chow, $8 \%$ maize oil and $44 \%$ condensed milk for 7 to 12 weeks ${ }^{48}$. In a hypercaloric diet model with fat, a diet was used containing $17.4 \%$ carbohydrate, $42.9 \%$ protein and $39.7 \%$ fat ${ }^{9}$. Another model used 55\% fat, $21 \%$ carbohydrate and $24 \%$ protein.

\section{Genetic models}

The genetic models to study obesity began to be used increasingly in the 1990s because of cloning and identification of the product of five different genes causing obesity. Furthermore, it was discovered that by crossing (QTL) with known genes, i.e., obese phenotypes vs identified genotype, the influence of quantitative gene loci, and its penetrance in the quantity of body fat and its distribution ${ }^{49,50}$. Furthermore, in the last few years, genetically modified or knockout animals have been produced to study new genes that are candidates to influence the rate of obesity $^{49}$. There are over 50 different types of genetic models of obesity in rodents ${ }^{51}$. The first five monogenic models of obesity were diabetic (db/db), obese(ob/ob) - these two in the same metabolic pathway, Tubby (tub), “Agouti” yellow $\left(\mathrm{A}^{\mathrm{y}}\right)$ and fat (fat). The "Agouti” rat was described for the first time over a century ago, and it was the first obesity gene to be cloned and characterized at the molecular level in1992. Today there are over 25 mutations in rodents known with "Agouti", 5 of them dominant genetic mutations. This rat, also known as yellow rat, expresses a very high amount of agouti protein coded by chromosome 2 . This leads to later obesity and hyperphagia. The function of this gene is to antagonize the melanocortin receptor with homology in our chromosome 20(20q11.2). This discovery led to finding that neural circuits were involved in regulating the energy balance. In humans agouti is expressed in several tissues, including adipose tissue, suggesting that it could be involved in regulating the energy balance. In studies on genetically modified rats with overexpression of agouti in adipose tissue, they were significantly heavier than the nongenetically modified ones, without any change in the amount of intake. This suggest that the increase of fatty mass in these rats could be the result of changes in energy expenditure $^{49,50 ; 52-55}$. At the end of 1994 the gene of the obese rat (ob/ob) was cloned, followed a year later by cloning the diabetic one (db/db). In experimental studies, it was found that a circulating factor of a normal rat or a db/db rat, when administered in an ob/ob rat, normalized its weight. But when this factor of a normal rat or an ob/ob was placed in a $\mathrm{db} / \mathrm{db}$ rat, there was no weight change. These results strongly suggested that both genes were from the same metabolic pathway, and that $\mathrm{db} / \mathrm{db}$ could be an ob/ob receptor, which was later proved. This factor was called leptin, i.e., a hormone produced by the ob/ob gene, that was responsible for communicating with the brain concerning the level of energy stored in adipose tissue in the form of fat. The ob/ob rats present a mutation in chromosome 6 and develop a syndrome together with hyperphagia, diabetes and obesity, whose origin is due to the absence of leptin or to the presence of non-functional leptin. In humans this gene is found in chromosome 7 (7q31.1). Afterwards it was discovered that gene $\mathrm{db} / \mathrm{db}$ was responsible for coding the leptin receptor and located in chromosome 1 (1q31) in humans. The $\mathrm{db} / \mathrm{db}$ rats presented a mutation in chromosome 4 , causing resistance to leptin. These animals showed hyperinsulinemia, glucose intolerance and neuroendocrine and thermogenic changes, besides hyperphagia and infertility ${ }^{49,50,54,55}$. Later the Tubby (tub) rat was cloned in a joint venture between the Jackson Laboratory, Sequana Therapeutics and the Millenium Group, But this line of tub rats came from a spontaneous mutation in 1977 in the Jackson laboratory, and presented as a recessive autosomal inheritance. They showed that the break in a protein sequence prevented a biochemical pathway that controls appetite and the processing of food. Later it was identified as an insulin-signaling protein. This mutation is located on chromosome a 7 of the rats and leads to slow onset obesity (age 3-4 months in males and 4-6 months in t/females) and moderate hypoglycemia, or even normoglycemia. But they have a high level of insulin and leptin. Its homology in humans is in chromosome 11 $(11 \mathrm{p} 15.5)^{49,50,54,55}$. The fat rat has a mutation in chromosome 8 and its phenotype is late obesity with infertility and hyperinsulinemia, and was identified in 1973. This gene produces the carboxypeptidase E enzyme, which has the function of producing biologically active forms of proinsulin and pro-opiomelanocortin. It homologue in humans is in chromosome 4 (4q32) $)^{49,50,54,55}$. Experimental models are important to evaluate specific causes and effects of obesity, but the study and extrapolation to humans is limited, since in most cases of human obesity it is the result of specific characteristics of individuals and interaction with the environment.

\section{Conclusion}

Investigating the causes and effects of obesity induced in experimental models may provide a better understanding of the physiopathogeny of obesity, which would mean new options for prevention and treatment. The best model to induce a disease is the one which best reproduces its pathophysiological characteristics. The multifactorial etiology of obesity provides several options for the development of experimental models to induce obesity. Animal studies have been performed, promoting neuroendocrine, dietary and genetic alterations. It is necessary to choose the model that is best adapted to the characteristics to be researched, whether they be environmental or genetic.

\section{References}

1. Gastrointestinal Surgery for Severe Obesity. NIH Consens Statement. 1991;9(1):1-2.

2. Field AE, Coakley EH, Must A, Spadano JL, Laird N, Dietz WH, et al. Impact of overweight on the risk of developing common chronic diseases during a 10-year period. Arch Intern Med. 2001;161:1581-6. 
3. York DA. Lessons from animal models of obesity. Endocrinol Metab Clin North Am. 1996;25(4):781-800.

4. Mozes S, Sefcikov Z, Lenhardt L, Racek L. Effect of adrenalectomy on the activity of small intestine enzymes in monosodium glutamate obese rats. Physiol Res. 2004;53(4):415-22.

5. Nakagawa T, Ukai K, Ohyama T, Gomita Y, Okamura H. Effects of chronic administration of sibutramine on body weight, food intake and motor activity in neonatally monosodium glutamate-treated obese female rats: relationship of antiobesity effect with monoamines. Exp Anim. 2000;49(4):239-49.

6. Shimizu Y, Yamazaki M, Nakanish K, Sakurai M, SanadaA, Takewaki T, et al. Enhanced responses of the chorda tympani nerve to sugars in the ventromedial hypothalamic obese rat. J Neurophysiol. 2003;90:128-33.

7. Chu SC, Chou YC, Liu JY, Chen CH, Shyu JC, Chou FP. Fluctuation of serum leptin level in rats after ovariectomy and the influence of estrogen supplement. Life Sci. 1999;64(24):2299-306.

8. Xu Y, Ramos EJ, Middleton F, Romanova I, Quinn R, Chen C, et al. Gene expression profiles post Roux-en-Y gastric bypass. Surgery. 2004;136(2):246-52.

9. Prunet-Marcassus B, Desbazeille M, Bros A, Louhce K, Delagrange P, Renard P, et al. Melatonin reduces body weight gain in Sprague Dawlwy rats with diet-induced obesity. Endocrinology. 2003;144:5347-52.

10. Lorden JF, Caudle A. Behavioral and endocrinological effects of single injections of monosodium glutamate in the mouse. Neurobehav Toxicol Teratol. 1986 Sep;8(5):509-19.

11. Guimaraes RB, Telles MM, Coelho VB, Mori RC, Nascimento CM, Ribeiro EB. Adrenalectomy abolishes the food-induced hypothalamic serotonin release in both normal and monosodium glutamate-obese rats. Brain Res Bull. 2002;58(4):363-9.

12. Martins AC, Souza KL, Shio MT, Mathias PC, Lelkes PI, Garcia RM. Adrenal medullary function and expression of catecholamine-synthesizing enzymes in mice with hypothalamic obesity. Life Sci. 2004;74(26):3211-22.

13. Miskowiak B, Partyka M. Effects of neonatal treatment with MSG (monosodium glutamate) on hypothalamopituitary-thyroid axis in adult male rats. Histol Histopathol. 1993;8(4):731-4.

14. Lorden JF, Caudle A. Behavioral and endocrinological effects of single injections of monosodium glutamate in the mouse. Neurobehav Toxicol Teratol. 1986;8(5):509-19.

15. Moreno G, Perello M, Camihort G, Luna G, Console G, Gaillard RC, et al. Impact of transient correction of increased adrenocortical activity in hypothalamodamaged, hyperadipose female rats. Int J Obes. (Lond) 2005 Oct 11.

16. Perello M, Gaillard RC, Chisari A, Spinedi E. Adrenal enucleation in MSG-damaged hyperleptinemic male rats transiently restores adrenal sensitivity to leptin. Neuroendocrinology. 2003;78(3):176-84.

17. Tokuyama K, Himms-Hagen J. Adrenalectomy prevents obesity in glutamate-treated mice. Am J Physiol. 1989;257(2 Pt 1):E139-44.

18. Shivshankar P, Devi SC. Screening of stimulatory effects of dietary risk factors on mouse intestinal cell kinetics. World J Gastroenterol. 2005;11(2):242-8.

19. Bunyan J, Murrell EA, Shah PP. The induction of obesity in rodents by means of monosodium glutamate. $\mathrm{Br} \mathrm{J}$ Nutr. 1976;35(1):25-39.

20. de Carvalho PP, Vargas AM, da Silva JL, Nunes MT, Machado UF. GLUT4 protein is differently modulated during development of obesity in monosodium glutamate-treated mice. Life Sci. 2002;71(16):1917-28.

21. de Mello MA, de Souza CT, Braga LR, dos Santos JW, Ribeiro IA, Gobatto CA. Glucose tolerance and insulin action in monosodium glutamate (MSG) obese exercisetrained rats. Physiol Chem Phys Med NMR. 2001;33(1):63-71.

22. de Souza CT, Nunes WM, Gobatto CA, de Mello MA. Insulin secretion in monosodium glutamate (MSG) obese rats submitted to aerobic exercise training. Physiol Chem Phys Med NMR. 2003;35(1):43-53.

23. Dolnikoff M, Martin-Hidalgo A, Machado UF, Lima FB, Herrera E. Decreased lipolysis and enhanced glycerol and glucose utilization by adipose tissue prior to development of obesity in monosodium glutamate (MSG) treated-rats. Int J Obes Relat Metab Disord. 2001;25(3):426-33.

24. Kanarek RB, Meyers J, Meade RG, Mayer J. Juvenile-onset obesity and deficits in caloric regulation in MSG-treated rats. Pharmacol Biochem Behav. 1979;10(5):717-21.

25. Moreno G, Perello M, Camihort G, Luna G, Console G, Gaillard RC, et al. Impact of transient correction of increased adrenocortical activity in hypothalamodamaged, hyperadipose female rats. Int J Obes. (Lond) 2005 Oct 11.

26. Diniz YS, Faine LA, Galhardi CM, Rodrigues HG, Ebaid GX, Burneiko RC, et al. Monosodium glutamate in standard and high-fiber diets: metabolic syndrome and oxidative stress in rats. Nutrition. 2005;21(6):749-55.

27. Dube MG, Xu B, Kalra PS, Sninsky CA, Kalra SP. Disruption in neuropeptide $\mathrm{Y}$ and leptin signaling in obese ventromedial hypothalamic-lesioned rats. Brain Res. 1999;816(1):38-46.

28. King BM. Ventromedial hypothalamic obesity: a reexamination of the irritative hypothesis. Neurosci Biobehav Rev. 1991;15(3):341-7.

29. King BM, Daigrepont PM, Michel RE, Zansler CA, Ahmed JI, Walker A, et al. Hypothalamic obesity: comparison of radio-frequency and electrolytic lesions in weanling rats. Physiol Behav. 1989;45(1):127-32.

30. King BM, Frohman LA. Hypothalamic obesity: comparison of radio-frequency and electrolytic lesions in male and female rats. Brain Res Bull. 1986;17(3):409-13.

31. King BM, Frohman LA. Nonirritative lesions of VMH: effects on plasma insulin, obesity, and hyperreactivity. Am J Physiol. 1985;248(6 Pt 1):E669-75.

32. Dube MG, Xu B, Kalra PS, Sninsky CA, Kalra SP. 
Disruption in neuropeptide $\mathrm{Y}$ and leptin signaling in obese ventromedial hypothalamic-lesioned rats. Brain Res. 1999;816(1):38-46.

33. Scallet AC, Olney JW. Components of hypothalamic obesity: bipiperidyl-mustard lesions add hyperphagia to monosodium glutamate-induced hyperinsulinemia. Brain Res. 1986;374(2):380-4.

34. Dube MG, Xu B, Kalra PS, Sninsky CA, Kalra SP. Disruption in neuropeptide $\mathrm{Y}$ and leptin signaling in obese ventromedial hypothalamic-lesioned rats. Brain Res. 1999;816(1):38-46.

35. Chu SC, Chou YC, Liu JY, Chen CH, Shyu JC, Chou FP. Fluctuation of serum leptin level in rats after ovariectomy and the influence of estrogen supplement. Life Sci. 1999;64(24):2299-306.

36. Shimizu H, Shimomura Y, Nakanishi Y, Futawatari T, Ohtani K, Sato N, et al. Estrogen increases in vivo leptin production in rats and human subjects. J Endocrinol. 1997;154(2):285-92.

37. Chen Y, Heiman ML. Increased weight gain after ovariectomy is not a consequence of leptin resistance. Am J Physiol Endocrinol Metab. 2001;280(2):E315-22.

38. Ainslie DA, Morris MJ, Wittert G, Turnbull H, Proietto J, Thorburn AW. Estrogen deficiency causes central leptin insensitivity and increased hypothalamic neuropeptide Y. Int J Obes Relat Metab Disord. 2001;25(11):1680-8.

39. Kimura M, Irahara M, Yasui T, Saito S, Tezuka M, Yamano $\mathrm{S}$, et al. The obesity in bilateral ovariectomized rats is related to a decrease in the expression of leptin receptors in the brain. Biochem Biophys Res Commun. 2002;290(4):1349-53.

40. Meli R, Pacilio M, Raso GM, Esposito E, Coppola A, Nasti A, et al. Estrogen and raloxifene modulate leptin and its receptor in hypothalamus and adipose tissue from ovariectomized rats. Endocrinology. 2004;145(7):3115-21.

41. Kamei Y, Suzuki M, Miyazaki H, Tsuboyama-Kasaoka N, Wu J, Ishimi Y, et al. Ovariectomy in mice decreases lipid metabolism-related gene expression in adipose tissue and skeletal muscle with increased body fat. J Nutr Sci Vitaminol. (Tokyo) 2005;51(2):110-7.

42. Pelleymounter MA, Baker MB, McCaleb M. Does estradiol mediate leptin's effects on adiposity and body weight? Am J Physiol. 1999;276(5 Pt 1):E955-63.

43. Shimomura K, Shimizu H, Tsuchiya T, Abe Y, Uehara Y, Mori M. Is leptin a key factor which develops obesity by ovariectomy? Endocrinol J. 2002;49(4):417-23.

44. Shimizu H, Ohtani K, Kato Y, Tanaka Y, Mori M. Withdrawal of [corrected] estrogen increases hypothalamic neuropeptide Y (NPY) mRNA expression in ovariectomized obese rat. Neurosci Lett. 1996;204(12):81-4.

45. Henry BA, Goding JW, Alexander WS, Tilbrook AJ, Canny BJ, Dunshea F, et al. Central administration of leptin to ovariectomized ewes inhibits food intake without affecting the secretion of hormones from the pituitary gland: evidence for a dissociation of effects on appetite and neuroendocrine function. Endocrinology. 1999;140(3):1175-82.

46. Ainslie DA, Morris MJ, Wittert G, Turnbull H, Proietto J, Thorburn AW. Estrogen deficiency causes central leptin insensitivity and increased hypothalamic neuropeptide Y. Int J Obes Relat Metab Disord. 2001;25(11):1680-8.

47. Naderali EK, Fatani S, Wiliams G. Chronic withdrawal of a high-palatable obesity-inducing diet completely reverses metabolic and vascular abnormalities associated with dietary-obesity in the rat. Atherosclerosis. 2004;172:63-9.

48. Meguid MM, Ramos EFB, Suzuki S, Xu Y, George ZM, Hughes K, et al. A Surgical rat model of human Roux-eny gastric bypass. J Gastrointest Surg. 2004;8:621-30.

49. Marques-Lopes I, Marti A, Moreno-Aliaga MJ, Martinez A. Aspectos geneticos da obesidade. Rev Nutr. 2004;17(3):327-38.

50. Chagnon Y C, Bouchard C. Genetics of obesity: advances from rodents studies. TGI. 1996;12(11).

51. Good D.J. Using obese mouse models in research: special considerations for IACUC members, animal care technicians, and researchers. Lab Animal. 2005;34(2):30-7.

52. Carroll L, Voisey J, Van Daall A. Mouse models of obesity. Clin Dermatol. 2004;22:345-9.

53. Mynatt RL, Miltenberger RJ, Klebig ML, et al. Combined effects of insulin treatment and adipose tissue-specific agouti expression on the development of obesity. Natl Acad Sci USA. 1997;94:919-22.

54. Brockmann GA, Bevova MR. Using mouse models to dissect the genetics of obesity. Trends Genet. 2002;18(7):367-76.

55. Robinson SW, Dinulesco DM, Cone RD. Genetic models of obesity and energy balance in the mouse. Ann Rev Genet. 2000;34:687-745.
Manoel R. M.Trindade

Rua Hilário Ribeiro, 144/601

90510-040 Porto Alegre - RS Brasil

manoeltr@portoweb.com.br
Conflict of interest: none Financial source: none

Received: July 05, 2006

Review: August 13, 2006

Accepted: September 18, 2006

\section{How to cite this article:}

Von Diemen V, Trindade EN, Trindade MR. Experimental model to induce obesity in rats. Acta Cir Bras. [serial on the Internet] 2006 Nov-Dec;21(6). Available from URL: http://www.scielo.br/acb. 